\title{
Edwardsiella tarda Hfq: impact on host infection and global protein expression
}

Yong-hua $\mathrm{Hu}^{1}$, Yong-xin $\mathrm{Li}^{1,2}$ and Li Sun ${ }^{1 *}$

\begin{abstract}
Hfq is an RNA-binding protein that plays an important role in many cellular processes. In this study, we examined the biological effect of the Hfa of Edwardsiella tarda, a severe fish pathogen with a broad host range that includes humans. To facilitate the study, a markerless hfa in-frame deletion wild type, TXhfq, was constructed. Compared to the wild type TX01, TXhfq exhibited (i) retarded planktonic and biofilm growth, (ii) decreased resistance against oxidative stress, (iii) attenuated overall virulence and tissue dissemination and colonization capacity, (iv) impaired ability to replicate in host macrophages and to block host immune response. Introduction of a trans-expressed hfa gene into TXhfq restored the lost virulence of TXhfq. To identify potential Hfq targets, comparative global proteomic analysis was conducted, which revealed that 20 proteins belonging to different functional categories were differentially expressed in TXhfq and TX01. Quantitative real time RT-PCR analysis showed that the mRNA levels of two thirds of the genes of the identified proteins were consistent with the proteomic results. Since TXhfa is dramatically attenuated in virulence, we further examined its potential as a naturally delivered vaccine administered via the immersion route in a flounder model. The results showed that TXhfq induced effective protection against lethal $E$. tarda challenge. Taken together, our study indicated that $\mathrm{Hfq}$ is required for the normal operation of $E$. tarda in multiple aspects, and that Hfa probably exerts a regulatory effect on a wide range of target genes at both transcription and post-transcription levels.
\end{abstract}

\section{Introduction}

Edwardsiella tarda is a Gram-negative, motile, rodshaped bacterium belonging to the family of Enterobacteriaceae. It is a serious fish pathogen that causes edwardsiellosis, a systematic disease that affects a wide range of farmed fish species including Japanese eel (Anguilla japonica, Temminck \& Schlegel, 1847), Japanese flounder (Paralichthys olivaceus, Temminck \& Schlegel 1846), turbot (Scophtalmus maximus, Linnaeus 1758), red sea bream (Pagrus major, Temminck \& Schlegel 1843), tilapia (Oreochromis niloticus, Linnaeus 1758), and channel catfish (Ictalurus punctatus, Rafinesque 1818) [1]. Heavy economic losses due to E. tarda-related edwardsiellosis have been reported in aquaculture industries worldwide [2]. In addition to fish, $E$. tarda is also a human pathogen and known to cause gastroenteritis and extraintestinal infections [3]. Recent studies indicate that $E$. tarda possesses numerous virulence factors, which participate in different aspects of host infection $[2,4]$. Currently, owing to the lack

\footnotetext{
* Correspondence: Isun@qdio.ac.cn

${ }^{1}$ Key Laboratory of Experimental Marine Biology, Institute of Oceanology,

Chinese Academy of Sciences, Qingdao 266071, China

Full list of author information is available at the end of the article
}

of effective vaccines, control of $E$. tarda in aquaculture depends mainly on the use of antibiotics in most countries including China.

Hfq was originally identified as a host factor required for RNA replication of phage Q $\beta$ in Escherichia coli [5], and was classified into the conserved RNA-binding Lsm (like-Sm)/Sm-like protein family found in both eukaryotes and prokaryotes [6]. Accumulating evidences have shown that Hfq is an RNA chaperone involved in posttranscriptional gene regulation via several mechanisms, including interaction with small RNAs (sRNAs) and facilitating their binding to target mRNA, modulating mRNA degradation, and regulating the process of mRNA translation [7]. For pathogenic bacteria such as Brucella abortus, E. coli, Legionella pneumophila, Pseudomonas aeruginosa, Salmonella Typhimurium, Vibrio cholerae, Yersinia enterocolitica, and Klebsiella pneumoniae, Hfq is known to be a virulence factor [8-18]. Inactivation of the $h f q$ gene leads to defect in a variety of biological aspects, notably cellular growth and motility, quorum sensing, stress tolerance, and infectivity $[19,20]$. However, to date very little study has been documented 
on the Hfq of fish pathogens, and for E. tarda, the role of Hfq is entirely unknown.

In the present study, we aimed to investigate the biological property of $\mathrm{Hfq}$ in E. tarda and, in particular, whether Hfq plays any role in E. tarda infection. For this purpose, we compared the effect of an $h f q$ wild type, TXhfq, to that of the wild type strain. We found that deletion of $h f q$ in $E$. tarda had pleiotropic effects on bacterial growth, infection, and global protein expression. Additionally, we also observed the potential of TXhfq as a naturally delivered vaccine to elicit protective immunity in host against $E$. tarda. Our results provide the first insight to the biological function of E. tarda $\mathrm{Hfq}$ as well as its applicability in the control of edwardsiellosis in aquaculture.

\section{Materials and methods}

\section{Ethics statement}

Experiments involving live animals were conducted in accordance with the "Regulations for the Administration of Affairs Concerning Experimental Animals" promulgated by the State Science and Technology Commission of Shandong Province. The study was approved by the ethics committee of Institute of Oceanology, Chinese Academy of Sciences. Efforts were taken to ensure that all research animals received good care and humane treatment as stipulated in the above regulations.

\section{Bacterial strains and growth conditions}

Escherichia coli BL21(DE3) was purchased from Tiangen (Beijing, China). E. coli S17-1入pir was purchased from Biomedal (Sevilla, Spain). E. tarda TX01 was isolated from diseased fish [21]. Bacteria were cultured in LuriaBertani broth (LB) at $37{ }^{\circ} \mathrm{C}$ (for E. coli) or $28{ }^{\circ} \mathrm{C}$ (for E. tarda). Where indicated, chloramphenicol, polymyxin B, and 2,2'dipyridyl were supplemented at the concentration of $30 \mu \mathrm{g} / \mathrm{mL}, 100 \mu \mathrm{g} / \mathrm{mL}$, and $100 \mu \mathrm{M}$ respectively. Biofilm growth on polystyrene surface was conducted as reported previously [22].

\section{Fish}

Clinically healthy Japanese flounder (Paralichthys olivaceus) (average $11.9 \mathrm{~g}$ ) were purchased from a local commercial fish farm. The fish were maintained at $\sim 19{ }^{\circ} \mathrm{C}$ in aerated seawater that was changed twice daily. The seawater was sand-filtered and activated carbonabsorbed, with $\mathrm{pH}$ of 8.1 , oxygen $>6 \mathrm{mg} / \mathrm{L}$, and ammonia $<0.1 \mathrm{mg} / \mathrm{L}$. Fish were acclimatized in the laboratory for two weeks before experimental manipulation. Fish were fed daily with commercial dry pellets (purchased from Shandong Sheng-suo Fish Feed Research Center, Shandong, China) at the amount of $\sim 1.2 \%$ body weight. Before experiment, fish (6\%) were randomly sampled and examined for the presence of bacteria in blood, liver, kidney, and spleen, and no bacteria were detected from the sampled fish. For tissue collection, fish were euthanized with an overdose of MS222 (tricaine methanesulfonate) (Sigma, USA) as described previously [23].

\section{Sequence analysis}

$h f q$ was cloned from $E$. tarda TX01 with primers F1/R1 (Table 1), which were designed based on the known $h f q$ sequence of E. tarda EIB202 and E. tarda FL6-60 (GenBank accession nos. ACY83199.1 and ADM40428.1 respectively). The sequence of Hfq was analyzed using the BLAST program at the National Center for Biotechnology Information (NCBI) and the Expert Protein Analysis System.

\section{hfq knockout}

The primers used in this study are listed in Table 1. To construct the $h f q$ knockout wild type TXHfq, in-frame deletion of a 222 bp segment (residues 6 to 79) of $h f q$ was performed by overlap extension PCR as follows: the first overlap PCR was performed with the primer pair F2/R2, the second overlap PCR was performed with the primer pair F3/R3, and the fusion PCR was performed with the primer pair F2/R3. The PCR products were inserted into the suicide plasmid pDM4 [24] at the BglII site, resulting in pDMHfq. S17-1 $\lambda$ pir was transformed with pDMHfq, and the transformants were conjugated with TX01 as described previously [21]. The transconjugants were selected on LB agar plates supplemented with $10 \%$ sucrose. One of the colonies that were resistant to sucrose and sensitive to chloramphenicol (marker of pDM4) was analyzed by PCR, and the PCR products were subjected to DNA sequencing to confirm in-frame deletion. This strain was named TXHfq.

\section{Table 1 Primers used in this study}

\begin{tabular}{ll}
\hline Primer & Sequences $\left(\mathbf{5}^{\prime} \rightarrow \mathbf{3}^{\prime}\right)^{\mathbf{a}}$ \\
\hline F1 & ATGGCTAAGGGGCATCT \\
R1 & TTATTCAGCGTCATCACTGC \\
F2 & GGATCCGGATTGATCCGGTCGCC (BamHI) \\
R2 & CTGCCTGCTTGCCCCTTAGCCATTCT \\
F3 & GGCAAGCAGGCAGCAGCTACCA \\
R3 & GGATCCCGGTCGGTCTCCAACTG (BamHI) \\
F4 & GATATCATGGCTAAGGGGCAATC (ECoRV) \\
R4 & GATATCTTCAGCGTCATCACTGC (ECORV) \\
HP1-F & CCCGGGATGCGAGCTGAAACCATTCTG (Smal) \\
HP1-R & CCCGGGTITAAGCATGATGCGCT (Smal) \\
HP2-F & TACGTAATGCTGATAATGCAAATATCAACT (SnaBI) \\
HP2-R & TACGTACAGGTGCGCGTAAACCACG (SnaBI) \\
DPFP-F & GATATCATGTCTCAGCCTCAGAGCG (ECoRV) \\
DPFP-R & GATATCCAGCGTCAGCAAACGCGT (ECORV) \\
\hline
\end{tabular}

attalicized nucleotides are restriction sites of the enzymes indicated in the brackets at the ends. 


\section{Complementation of $h f q$ mutation}

The plasmid pJTHfq, which expresses $h f q$ constitutively, was created as follows. $h f q$ was amplified by PCR with primers F4/R4; the PCR product was ligated with the TA cloning vector pBS-T (Tiangen, Beijing, China), and the recombinant plasmid was digested with SmaI. The fragment containing $h f q$ was retrieved and inserted into plasmid pBT3 [25] at the EcoRV site, resulting in pBT3Hfq. pBT3Hfq was digested with SwaI, and the fragment carrying $h f q$ was inserted into plasmid pJT [26]

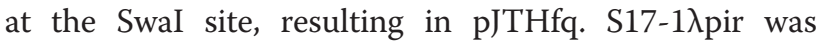
transformed with $\mathrm{pJT}$, and the transformants were conjugated with TXHfq. The transconjugants were selected on LB agar plates supplement with tetracycline (resistance marker of $\mathrm{pJT}$ ) and polymyxin $\mathrm{B}$. One of the transformants was named TXHfqC.

\section{$\mathrm{H}_{2} \mathrm{O}_{2}$ survival analysis}

$\mathrm{H}_{2} \mathrm{O}_{2}$ survival analysis was performed as reported previously [27].

\section{Virulence analysis}

The median lethal dose $\left(\mathrm{LD}_{50}\right)$ of TX01, TXHfq, and TXHfqC was determined as described previously [23]. For tissue dissemination and colonization analysis, TXHfq and TX01 were cultured in LB medium at $28{ }^{\circ} \mathrm{C}$ for different times until $\mathrm{OD}_{600}$ of 0.8 . The cells were washed with PBS and resuspended in seawater to $1 \times 10^{8} \mathrm{CFU} / \mathrm{mL}$. Flounder were immersed in seawater containing TXHfq or TX01 or PBS (control) for $2 \mathrm{~h}$. The fish were then moved to 58-liter tanks containing fresh seawater and reared normally as described above in the section of "Fish". At 1 , $2,3,4,5$, and 7 days post-infection (dpi), blood, kidney, liver, and spleen were taken aseptically from the fish (five/time point). The tissues were homogenized in a glass homogenizer containing PBS $(100 \mu \mathrm{L} / \mathrm{mg}$ tissue $)$. The homogenates and blood were diluted serially and plated in triplicate on LB agar plates. The plates were incubated at $28{ }^{\circ} \mathrm{C}$ for $48 \mathrm{~h}$, and the colonies that appeared on the plates were enumerated. The genetic identity of the colonies was verified by PCR with specific primers [27] and sequence analysis of selected PCR products. The experiment was conducted in three replicates at the same time, and the mean values were given in the results.

\section{Bacterial replication in macrophages}

Flounder head kidney (HK) macrophages were prepared as described previously [28]. The macrophages were cultured in L-15 medium (Thermo Scientific HyClone, Beijing, China) in 96-well culture plates $\left(\sim 10^{5}\right.$ cells/well). TXHfq, TX01, and TXHfqC suspensions in PBS were prepared as described above and added to macrophages $\left(10^{6} \mathrm{CFU} /\right.$ well $)$. The cells were incubated at $25^{\circ} \mathrm{C}$ for
$0.5 \mathrm{~h}$. After incubation, the cells were washed with PBS for three times and added with fresh L-15 containing 100 $\mathrm{U} / \mathrm{mL}$ penicillin and streptomycin (Thermo Scientific HyClone, Beijing, China), followed by incubation at $25^{\circ} \mathrm{C}$ for $1.5 \mathrm{~h}$ to kill extracellular bacteria. The plates were then washed three times with PBS and incubated at $28{ }^{\circ} \mathrm{C}$ for $1 \mathrm{~h}, 2 \mathrm{~h}, 4 \mathrm{~h}$, and $8 \mathrm{~h}$. After incubation, the plates were washed with PBS, and the cells were lysed with $100 \mu \mathrm{L} 1 \%$ Triton X-100. The cell lysate was serially diluted and plated in triplicate on LB agar plates. The plates were incubated at $28{ }^{\circ} \mathrm{C}$ for $48 \mathrm{~h}$, and the colonies that emerged on the plates were counted. The identities of the colonies were verified as described above.

\section{Reactive oxygen species (ROS) production}

ROS production was determined as follows. Flounder HK macrophages in a 96-well microplate $\left(\sim 10^{5}\right.$ cells/well $)$ were incubated with TXhfq, TX01, or TXhfqC $\left(10^{6} \mathrm{CFU} /\right.$ well) for $1 \mathrm{~h}$ or $2 \mathrm{~h}$. The plate was washed with PBS for three times. One hundred microliters of $1 \mathrm{mg} / \mathrm{mL}$ nitroblue tetrazolium (Sangon, Shanghai, China) in L-15 was added to the cells. After incubation at $25{ }^{\circ} \mathrm{C}$ for $2 \mathrm{~h}$, the reaction was stopped by adding $100 \%$ methanol. The plate was washed with $70 \%$ methanol, and the reduced formazan was solubilized in $100 \mu \mathrm{L}$ of $2 \mathrm{M} \mathrm{KOH}$ and $120 \mu \mathrm{L}$ of dimethyl sulfoxide. The plate was read at $630 \mathrm{~nm}$ with a microplate reader.

\section{Nitric oxide (NO) assay}

NO production was determined as follows. Flounder HK macrophages in a 96-well microplate $\left(\sim 10^{5}\right.$ cells/well $)$ were incubated with TXhfq, TX01, or TXhfqC $\left(10^{6} \mathrm{CFU} /\right.$ well) for $1 \mathrm{~h}$ or $2 \mathrm{~h}$. The supernatants were removed to a separate 96 -well plate $(50 \mu \mathrm{L} /$ well), followed by adding into each well $100 \mu \mathrm{L}$ of $1 \%$ sulphanilamide and $100 \mu \mathrm{L}$ of $0.1 \% \mathrm{~N}$-naphthylethylene-diamine (Sigma, St. Louis, MO, USA). The plate was read at $540 \mathrm{~nm}$, and the molar concentration of nitrite was determined from standard curve generated using known concentrations of sodium nitrate.

\section{Two-dimensional gel electrophoresis (2-DE)}

TX01 and TXhfq were cultured in LB medium at $28{ }^{\circ} \mathrm{C}$ and collected at $\mathrm{OD}_{600} 0.8$ by centrifugation at $4000 \mathrm{~g}$ for $15 \mathrm{~min}$ at $4{ }^{\circ} \mathrm{C}$. The cells were washed with PBS for three times and resuspended in extraction solution (7 M urea, $2 \mathrm{M}$ thiourea, 4\% CHAPS, $40 \mathrm{mM}$ DTT, 2\% IPG buffer). The cells were disrupted by intermittent sonic oscillation for a total of $15 \mathrm{~min}$ on ice with intervals of $30 \mathrm{~s}$. Unbroken cells and cellular debris were removed by centrifugation at $20000 \mathrm{~g}$ for $60 \mathrm{~min}$. The proteins in the supernatant were purified with 2D-Clean-Up Kit (GE Healthcare, Piscataway, NJ, USA) and resuspended in IEF sample loading solution (7 M urea, $2 \mathrm{M}$ thiourea, 2\% CHAPS, $40 \mathrm{mM}$ DTT, 0.5\% IPG buffer, $0.002 \%$ 
bromophenol blue). Protein concentration was determined using the BCA Protein Assay Kit (Sangon Biotech, Shanghai, China). Two-DE was performed as reported previously [29]. The gel images were acquired using ImageScanner III (GE healthcare, Piscataway, NJ, USA) and analyzed with ImageMaster 2D Platinum 6.0 (GE healthcare, Piscataway, NJ, USA). Triplicate runs were made for each sample to ensure gel reproducibility. For comparative analysis, the percentage intensity volume (\%vol) of each spot was used for comparison of matched spots between TXhfq and TX01. To reduce potential errors, a ratio of $\geq$ 2 (or $\leq 0.5)$ and analysis of variance (ANOVA) $<0.05$ were taken as a threshold for differential expression.

\section{In-gel enzymatic digestion and matrix-assisted laser desorption/ionization time of flight (MALDI-TOF) mass spectrometry analysis}

The differentially expressed protein spots were picked from the gels and washed once with $500 \mu \mathrm{L}$ water and three times with $500 \mu \mathrm{L} 25 \mathrm{mM}$ ammonium bicarbonate in $50 \%$ acetonitrile for $60 \mathrm{~min}$. The gel spots were dehydrated by addition of $500 \mu \mathrm{L}$ acetonitrile, and the samples were then incubated in $200 \mu \mathrm{L} 10 \mathrm{mM}$ DTT at $56{ }^{\circ} \mathrm{C}$ for $60 \mathrm{~min}$ to reduce disulfide bonds. Alkylation of cysteines was performed by adding $200 \mu \mathrm{L} 55 \mathrm{mM}$ iodoacetamide, and the samples were incubated at room temperature for $45 \mathrm{~min}$ in the dark. The samples were washed with PBS and dehydrated with $500 \mu \mathrm{L}$ acetonitrile. The samples were incubated in trypsin solution $(10 \mu \mathrm{g} / \mathrm{mL}$ in PBS) for $30 \mathrm{~min}$ on ice. After incubation, the remaining trypsin solution was removed, and $25 \mu \mathrm{L}$ of PBS was added to the samples. Proteolysis was performed at $37{ }^{\circ} \mathrm{C}$ overnight and stopped by adding 5\% formic acid. MALDI-TOF mass spectrometry (MS) analysis was performed with ultrafleXtreme (Bruker, Germany) as follows. One microliter peptide solution was dripped onto the Anchorchip target plate and allowed it to dry at room temperature. Matrix solution (CHCA) was added to the plate, and the plate was loaded into the spectrometer. The mass range was from 500 to $3500 \mathrm{Da}$, and the scan resolution was 50000 . After the scan, five most abundant MS peaks were selected for MS/MS scan. Protein identification was as described previously [29].

Quantitative real-time reverse transcription-PCR (qRT-PCR) TXhfq and TX01 were cultured in in LB medium to an $\mathrm{OD}_{600}$ of 0.8 . Total RNA was extracted with EZNA Total RNA Kit (Omega Bio-tek, Doraville, GA, USA). The RNA was treated with RNase-free DNaseI (TaKaRa, Dalian, China). One microgram of RNA was used for cDNA synthesis with the Superscript II reverse transcriptase (Invitrogen, Carlsbad, CA, USA). qRT-PCR was carried out in an Eppendorf Mastercycler (Eppendorf, Hamburg, Germany) using SYBR ExScript qRT-PCR Kit
(Takara, Dalian, China) as described previously [30]. Melting curve analysis of amplification products was performed at the end of each PCR to confirm that only one PCR product was amplified and detected. The expression level of the target genes was analyzed using comparative threshold cycle method $\left(2^{-\Delta \Delta C T}\right)$ with $16 \mathrm{~s}$ rRNA as an internal control. The data are given in terms of mRNA levels relative to that of $16 \mathrm{~s}$ rRNA and expressed as means plus or minus standard errors of the means (SE).

\section{Antibody preparation and Western blot}

To obtain antibodies against hypothetical protein 1 (HP1), hypothetical protein 2 (HP2), and the dyp-type peroxidase family protein (DPFP), His-tagged recombinant proteins of HP1, HP2, and DPFP were prepared. For this purpose, the plasmids $\mathrm{pHP} 1, \mathrm{pHP} 2$, and $\mathrm{pDPFP}$, which express HP1, HP2, and DPFP respectively, were constructed as follows. The coding sequences of HP1, HP2, and DPFP were amplified by PCR with primer pairs HP1-F/HP1-R, HP2-F/HP2-R, and DPFP-F/DPFP$\mathrm{R}$, respectively (Table 1 ). The PCR products were ligated with the pEASY-E2 (TransGen, Beijing, China), resulting in $\mathrm{pHP} 1, \mathrm{pHP} 2$, and $\mathrm{pDPFP}$. For protein preparation, Escherichia coli BL21(DE3) (Tiangen, Beijing, China) was transformed separately with the plasmids. The transformants were cultured in LB medium at $37^{\circ} \mathrm{C}$ to mid-log phase, and expression of recombinant proteins was induced by adding isopropyl- $\beta-D$-thiogalactopyranoside to a final concentration of $0.4 \mathrm{mM}$. Growth was continued at $37{ }^{\circ} \mathrm{C}$ for $5 \mathrm{~h}$, and recombinant proteins were purified using Ni-NTA agarose (QIAGEN, Valencia, CA, USA) as recommended by the manufacturer. The purified proteins were dialyzed for $24 \mathrm{~h}$ against PBS, and protein concentrations were determined using BCA Protein Assay Kit (Sangon Biotech, Shanghai, China). Rat antibodies against the recombinant proteins were prepared as described previously [31]. For Western blot, equal amounts of proteins from TXhfq and TX01 prepared above were resolved in 12\% SDS-PAGE and transferred onto nitrocellulose membranes (Amersham, Cambridge, UK). Immunoblot was performed as reported previously [32] using rat polyclonal antibodies against recombinant HP1, HP2, and DPFP prepared above. Densitometry was performed using the Sensiansy gel analysis system (Shanghai Peiqing Science \& Technology. Co., Ltd, China).

\section{Vaccination}

TXhfq was cultured in LB medium as described above and resuspended in seawater to $10^{8} \mathrm{CFU} / \mathrm{mL}$. Japanese flounder were divided into two groups (150 fish/group) named A and B. Group A was immersed in TXhfq bath for $1 \mathrm{~h}$; group B (control) was similarly immersed in seawater containing PBS. After immersion treatment, fish 
were placed into new 660-liter tanks and washed with fresh seawater to remove any bacteria that had been carried over from the immersion seawater. The fish were then reared under normal conditions as described above in the section of "Fish". At one month post-vaccination, 50 fish from each group were taken and challenged via intraperitoneal injection with TX01. Similarly, at two months post-vaccination, 50 fish from each group were taken and challenged with TX01. Mortality was monitored over a period of 20 days after challenge. Three dying fish were randomly selected for the examination of bacterial recovery from liver, blood, and spleen as described above. Relative percent of survival (RPS) was calculated according to the following formula: RPS $=\{1-(\%$ mortality in vaccinated fish $/ \%$ mortality in control fish) $\} \times 100$. The vaccination experiment was performed in duplicate at the same time.

\section{Enzyme-linked immunosorbent assay (ELISA)}

Sera were taken from vaccinated fish and control fish at one- and two-month post-vaccination and diluted serially in two-fold in PBS. Serum antibody against rEta1 was determined by ELISA analysis as described previously [33]. The assay was conducted with sera from five fish (each as an individual sample), and the mean values were given in the results.

\section{Statistical analysis}

Statistical analyses were performed with the SPSS 18.0 package (SPSS Inc., Chicago, IL, USA). Chi-square test with Yates' correction was used for mortality analysis, and analysis of variance (ANOVA) was used for all other analyses. Except where otherwise indicated, all in vitro experiments were performed at a single time in three replicates, and the results are shown as means plus or minus standard errors of the means (SE). For in vivo experiments, the number of replicate was indicated in the respective methods. In all cases, significance was defined as $P<0.05$.

\section{Results}

\section{Construction of an E. tarda $\Delta h f q$ wild type}

Hfq of E. tarda is composed of 102 residues and shares $100 \%$ and $83.5 \%$ overall sequence identities with the $\mathrm{Hfq}$ of Edwardsiella ictaluri and E. coli respectively. To examine its functional importance, the $h f q$ gene of $E$. tarda TX01, a highly pathogenic strain, was knocked out by markerless in-frame deletion of a region encoding amino acid residues 6 to 76 . The resulting wild type was named TXhfq.

\section{Mutation of $h f q$ has multiple effects}

(i.) Effect on growth and survival under different conditions
Growth analysis showed that when cultured in LB medium, TXhfq exhibited a slower generation time than TX01 at the logarithmic phase but reached similar cell densities as TX01 at the stationary phase (Figure 1). When cultured in LB medium supplemented with the iron chelator 2,2'dipyridyl, the growths of both TX01 and TXhfq were retarded; however, compared to TX01, TXhfq exhibited a much slower growth rate and a much lower maximum cell density at the stationary phase. Examination of biofilm growth on polystyrene surface indicated that TXhfq produced significantly less (3.1 fold) biofilm than TX01 (see Additional file 1). In the presence of $\mathrm{H}_{2} \mathrm{O}_{2}$, which damages bacterial cells via its oxidizing effect, the survival rate of TXhfq $(2.8 \% \pm 1.1)$ was significantly lower than that of TX01 $(21.8 \% \pm 2.2)$.

\section{(ii.) Effect on overall bacterial virulence}

Comparative $\mathrm{LD}_{50}$ analysis showed that TXhfq exhibited a $\operatorname{LD}_{50}\left(1.31 \times 10^{8} \mathrm{CFU} /\right.$ fish $)$ that is more than 600 fold higher that of TX01 $\left(1.9 \times 10^{5} \mathrm{CFU} /\right.$ fish $)$. When flounder were infected with the same dose of TX01 and TXhfq via immersion, TX01 recoveries from the blood, kidney, liver, and spleen of the infected fish increased from 1,2 , and $3 \mathrm{dpi}$, and mortality began to occur at 4 dpi (Figure 2A). In contrast, TXhfq recoveries from blood, kidney, liver, and spleen decreased with time and became undetectable after 7 dpi (Figure 2B).

(iii.) Effect on resistance against the immune response of host macrophages

To examine whether $h f q$ mutation affected the ability of $E$. tarda to block activation of host phagocytes, flounder HK macrophages were infected with TXhfq or TX01, and cellular productions of ROS and NO were

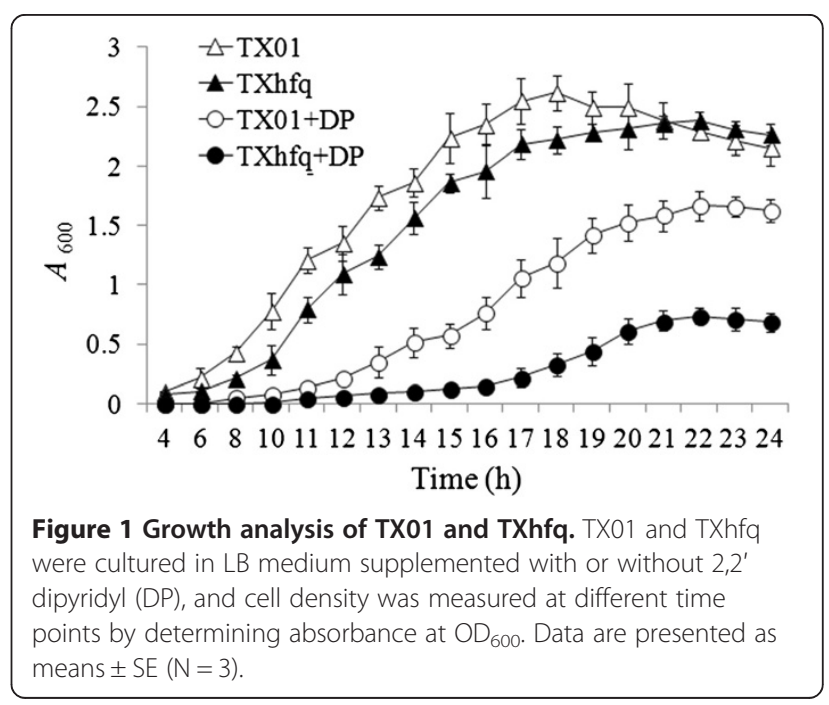





Figure 2 Invasion of TX01 (A) and TXhfq (B) into fish tissues following infection. Flounder were infected via immersion with the same dose of TX01 or TXhfq. Bacterial recovery from the liver, spleen, kidney, and blood of the infected fish was determined at different time points (no data on the group of TX01-infected fish at $7 \mathrm{dpi}$, because no fish survived to this point). The results are the means of three replicates and shown as means $\pm \mathrm{SE}$. CFU: colony forming unit. The $\mathrm{Y}$-axis represents the CFU number per mg of tissue (or per $\mathrm{mL}$ of blood) expressed in logarithmic form.

determined. The results showed that both ROS and NO levels in TXhfq-infected cells were significantly higher than those in TX01-infected cells (Figure 3). Intracellular bacterial recovery analysis showed that after invasion into HK macrophages, TX01 multiplied inside the cells and increased in number as the time progressed, whereas the intracellular number of TXhfq declined with time (Figure 4).

\section{Genetic complementation of $h f q$ deletion and its effect on virulence}

To examine whether the virulence defect observed with TXhfq was indeed due to $h f q$ deletion, the strain TXhfqC was created, which is a genetic variant of TXhfq that expresses $h f q$ in trans from a plasmid. In contrast to TXhfq, TXhfqC exhibited a $\mathrm{LD}_{50}\left(1.2 \times 10^{5} \mathrm{CFU} /\right.$ fish $)$ comparable to that of TX01. Following infection of
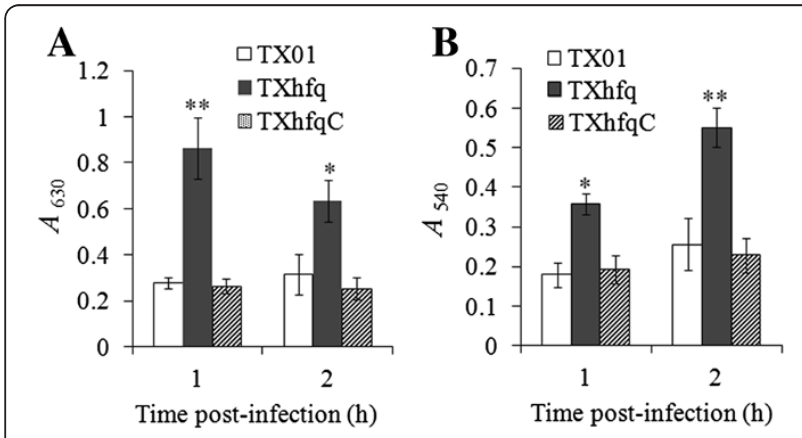

Figure 3 Effect of TXhfq, TX01, and TXhfqC on the immune response of macrophages. Flounder head kidney macrophages were infected with TXhfq, TX01, or TXhfqC, and reactive oxygen species (A) and nitric oxide (B) productions in the cells were determined at $1 \mathrm{~h}$ and $2 \mathrm{~h}$ post-infection. Data are presented as means $\pm \mathrm{E}(\mathrm{N}=3)$. ${ }^{*} P<0.05,{ }^{* *} P<0.01$.

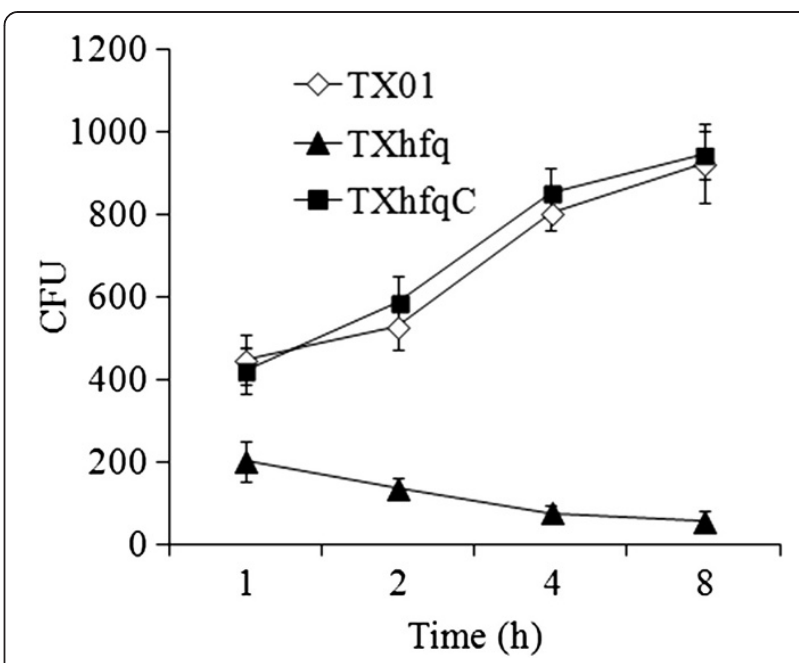

Figure 4 Multiplication of TXhfq, TX01, and TXhfqC in host macrophages. Flounder head kidney macrophages were infected with TXhfq, TX01, or TXhfqC. After removing uninfected bacteria, the cells were incubated at $28^{\circ} \mathrm{C}$ for different hours, and intracellular bacterial recovery was determined by plate count. Data are presented as means $\pm E(N=3)$.

flounder $\mathrm{HK}$ macrophages, TXhfqC-induced productions of ROS and NO were similar in levels to those induced by TX01 infection (Figure 3). Likewise, the intracellular multiplication capacity of TXhfqC was comparable to that of TX01 (Figure 4).

\section{Comparative analysis of the protein expression profiles in TXhfq and TX01}

\section{(i.) Two-DE protein maps of TXhfq and TX01}

To examine whether there was any difference in the protein profiles of TXhfq and TX01, whole cell proteins of the two strains were subjected to 2-DE analysis. Proteins whose expressions differed by more than 2-fold were further analyzed and listed as putative targets of Hfq regulation. The results showed that 20 protein spots exhibiting apparently differential expressions in TXhfq and TX01 were identified (Figure 5). Of these proteins, eight were significantly upregulated (ratio of TXhfq/ TX01 $\geq 2, P \leq 0.05)$ and twelve were significantly downregulated (ratio of TX01/TXhfq $\geq 2, P \leq 0.05$ ).

(ii.) Mass spectral identification of differentially expressed proteins

The 20 differentially expressed protein spots were subjected to MALDI-TOF/TOF analysis. Fifteen protein spots were successfully identified and grouped into seven functional categories (Table 2). Three proteins (rpsA, Tuf2, and Tsf) belong to the translation group, five proteins 

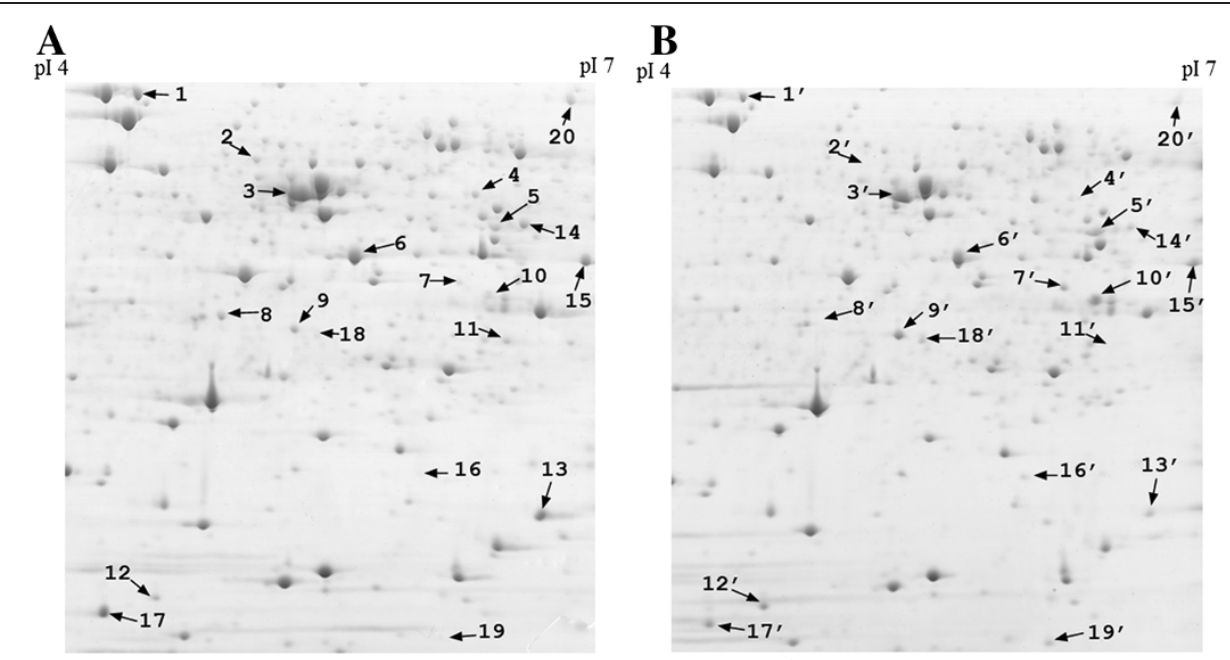

Figure 5 Representative 2-DE maps showing the protein profiles of TX01 and TXhfq. Whole cell proteins prepared from TX01 (A) and TXhfq (B) were subjected to 2-DE analysis. Numbers indicate protein spots with differential expression.

(YgeW, ybaS, cysteine synthase, putative iron-containing alcohol dehydrogenase, and dyp-type peroxidase) belong to the metabolism group, one protein (Mrp) is involved in transport, one protein (FkpA) is a putative chaperone, two proteins (OmpR and YqjD) belong to membrane proteins, and one protein (IscU) plays a role in iron-sulfur cluster assembly. The remaining two proteins are hypothetical proteins with unknown functions.

(iii.) Validation of differential expression of selected proteins at mRNA level

qRT-PCR (which determines the mRNA level) (Table 3) showed that the genes encoding Mrp, Dyp-type peroxidase, hypothetical protein 2, and FkpA were upregulated in TXhfq, while the genes encoding hypothetical protein 1 , YgeW, ybaS, OmpR, YqjD and cysteine synthase were downregulated in TXhfq, which is consistent with the 2DE protein profiles. The expressions of the genes encoding RpsA, Tuf2, Tsf, IscU, and the putative iron-containing alcohol dehydrogenase were comparable in the wild type and wild type strains. Three proteins were selected for further analysis by Western blot. The results showed that hypothetical protein 1 , which was downregulated in TXhfq by 2-DE and qRT-PCR analysis, was apparently detected in TX01 but was undetectable in TXhfa, while hypothetical protein 2 and the dyp-type peroxidase family protein, both were upregulated in TXhfq by 2-DE and qRT-PCR, were produced more abundantly in TXhfq than in TX01 (fold difference $\sim 2.8$ and 4.1 respectively) (Figure 6).

\section{The potential of TXhfq as an immersion vaccine}

Since TXhfq is dramatically decreased in virulence, we examined its potential as a live attenuated vaccine delivered via the natural route. For this purpose, flounder were immunized with live TXhfq via bath immersion. The fish were challenged with TX01 at one month and two months postvaccination and monitored for mortality. The results showed that mortality began to occur at 4 days and 3 days post-challenge for TXhfq-vaccinated fish and control fish respectively, and that mortality stopped at 14 days and 12 days post-challenge for TXhfq-vaccinated fish and control fish respectively. The accumulated mortalities of TXhfqvaccinated fish were $24 \%$ and $32 \%$ at one month and two months post-vaccination respectively, while the accumulated mortalities of the control fish (mock vaccinated with PBS) were $100 \%$ and $92 \%$ at one month and two months postvaccination respectively. Based on these results, the protection rates, in terms of PRS, of TXhfq as an immersion vaccine were $76 \%$ and $65 \%$ respectively at one month and two months post-vaccination. The two protection rates were statistically comparable. Comparable results were obtained in the duplicate vaccination trial, in which the accumulated mortalities of TXhfq-vaccinated fish were $20 \%$ and $30 \%$ at one month and two months post-vaccination respectively, while the accumulated mortalities of the control fish were 96\% and $98 \%$ at one month and two months postvaccination respectively. Examination of moribund fish indicated that TX01 was the only type of bacterium isolated from the liver, spleen, and blood, suggesting that mortality was caused by the experimental challenge. ELISA analysis showed that specific serum antibodies (titers $2^{6}$ and $2^{5}$ respectively) were produced in TXhfq-vaccinated fish at one month and two months post-vaccination.

\section{Discussion}

It has been observed that for many bacterial species, mutation of $h f q$ has a profound effect on cell growth, 
Table 2 Summary of the differentially expressed proteins

\begin{tabular}{|c|c|c|c|c|c|c|c|}
\hline Spot no. ${ }^{a}$ & NCBI no. & Protein name & Abrr. & $\begin{array}{l}\text { MASCOT } \\
\text { score }^{b}\end{array}$ & $\begin{array}{l}\text { Theoretical } \\
\mathrm{pl} / \mathrm{Mr}(\mathrm{kD})\end{array}$ & Coverage (\%) & $\begin{array}{l}\text { Fold ratio } \\
\text { wild type/wild type } \\
(\text { mean } \pm S D)^{d}\end{array}$ \\
\hline \multicolumn{8}{|c|}{ Translation } \\
\hline $1^{\mathrm{e}}$ & gi|269139520 & $\begin{array}{l}\text { rpsA gene product [Edwardsiella tarda EIB202]: } \\
30 \text { S ribosomal protein S1 }\end{array}$ & RpsA & 351 & $4.61 / 61.17$ & 41.65 & $0.42 \pm 0.05$ \\
\hline 3 & gi|18858425 & $\begin{array}{l}\text { tuf2 gene product [Edwardsiella tarda EIB202]: } \\
\text { elongation factor Tu }\end{array}$ & Tuf2 & 381 & $4.91 / 43.43$ & 54.31 & $0.35 \pm 0.09$ \\
\hline 6 & gi|269138094 & $\begin{array}{l}\text { tsf gene product [Edwardsiella tarda ElB202]: } \\
\text { translation elongation factor Ts }\end{array}$ & Tsf & 223 & $5.3 / 30.70$ & 36.84 & $0.45 \pm 0.07$ \\
\hline \multicolumn{8}{|c|}{ Metabolism } \\
\hline 4 & gi|294637737 & $\begin{array}{l}\text { Putative carbamoyltransferase YgeW } \\
\text { [Edwardsiella tarda ATCC 23685] }\end{array}$ & YgeW & 65.1 & $6.07 / 44.38$ & 17.97 & $0.21 \pm 0.12$ \\
\hline 7 & gi|269138485 & $\begin{array}{l}\text { Dyp-type peroxidase family protein } \\
\text { [Edwardsiella tarda EIB202] }\end{array}$ & & 260 & $5.76 / 33.27$ & 38.46 & $3.62 \pm 0.78$ \\
\hline 8 & gi|269140209 & $\begin{array}{l}\text { ybaS gene product [Edwardsiella tarda EIB202]: } \\
\text { glutaminase }\end{array}$ & YbaS & 362 & $4.83 / 33.06$ & 81.35 & $-\infty$ \\
\hline 14 & gi|387866356 & $\begin{array}{l}\text { Putative iron-containing alcohol dehydrogenase } \\
\text { [Edwardsiella tarda FL6-60] }\end{array}$ & & 218 & $5.73 / 42.61$ & 74 & $0.27 \pm 0.06$ \\
\hline 15 & gi|469762796 & Cysteine synthase [Edwardsiella tarda C07-087] & & 199 & $6.03 / 33.99$ & 77 & $0.46 \pm 0.05$ \\
\hline \multicolumn{8}{|l|}{ Transport } \\
\hline 5 & gi|387867244 & $\begin{array}{l}\text { Mrp (Multiple resistance and pH adaptation) } \\
\text { protein [Edwardsiella tarda FL6-60] }\end{array}$ & Mrp & 340 & $6.22 / 39.70$ & 26.76 & $2.81 \pm 1.11$ \\
\hline \multicolumn{8}{|c|}{ Chaperones } \\
\hline 10 & gi|269140581 & $\begin{array}{l}\text { fkpA gene product [Edwardsiella tarda EIB202]: } \\
\text { FKBP-type peptidyl-prolyl cis-trans isomerase }\end{array}$ & FkpA & 425 & $8.7 / 28.76$ & 58.39 & $4.24 \pm 1.35$ \\
\hline \multicolumn{8}{|c|}{ Membrane proteins } \\
\hline 11 & gi|269140620| & $\begin{array}{l}\text { ompR gene product [Edwardsiella tarda EIB202]: } \\
\text { osmolarity response regulator }\end{array}$ & OmpR & 127 & $6.31 / 27.41$ & 38.91 & $-\infty$ \\
\hline 13 & gi|304557842 & $\begin{array}{l}\text { Uncharacterized membrane protein YqjD } \\
\text { [Edwardsiella tarda FL6-60] }\end{array}$ & YqjD & 600 & $6.26 / 10.94$ & 82.18 & $0.25 \pm 0.04$ \\
\hline \multicolumn{8}{|c|}{ Cellular processes } \\
\hline 12 & gi|269140157 & $\begin{array}{l}\text { isc } U \text { gene product [Edwardsiella tarda EIB202]: } \\
\text { FeS cluster assembly scaffold }\end{array}$ & $\mathrm{IscU}$ & 102 & $4.74 / 13.86$ & 55.47 & $2.23 \pm 0.62$ \\
\hline \multicolumn{8}{|c|}{ Unknown function and hypothetical protein } \\
\hline 2 & gi|269139286 & Hypothetical protein 1 [Edwardsiella tarda ElB202] & & 153 & $5.64 / 58.02$ & 29.04 & $-\infty$ \\
\hline 9 & gi|269140100 & Hypothetical protein 2 [Edwardsiella tarda ElB202] & & 318 & $5.33 / 33.70$ & 54.90 & $3.21 \pm 1.28$ \\
\hline $16^{\mathrm{e}}$ & NA & NA & NA & NA & NA & NA & $5.21 \pm 1.25$ \\
\hline 17 & NA & NA & NA & NA & NA & NA & $0.31 \pm 0.05$ \\
\hline 18 & NA & NA & NA & NA & NA & NA & $2.94 \pm 0.85$ \\
\hline 19 & NA & NA & NA & NA & NA & NA & $4.22 \pm 1.77$ \\
\hline 20 & NA & NA & NA & NA & NA & NA & $0.32 \pm 0.06$ \\
\hline
\end{tabular}

${ }^{a}$ Spot ID represents the number on the 2-DE gels (Figure 5).

${ }^{b}$ MOWSE score is $-10 \log (p)$, where $p$ is the probability that the observed match is a random event. Based on the NCBInr database using the MASCOT searching program as MS/MS data. Scores greater than 65 are significant $(p<0.05)$.

'Number of amino acids spanned by the assigned peptides divided by the protein sequence length.

${ }^{d}$ Mean, the average protein abundance ratio for three paired samples. SD means the standard deviation of protein abundance ratios of one certain spot of three paired samples.

${ }^{\mathrm{e}}$ Not analyzed.

while in other bacteria, such as Haemophilus influenzae and Serratia sp, growth is hardly impaired by $h f q$ deletion $[19,34,35]$. In this study, we found that compared to the wild type TX01, the $\Delta h f q$ wild type TXhfq exhibited a slight growth difference when cultured in rich medium. However, TXhfq growth was severely retarded when the bacterium was cultured in iron-depleted medium. This result is in agreement with the reports 


\begin{tabular}{|c|c|c|c|}
\hline Spo no. & Description & $\begin{array}{l}\text { Protein level } \\
\text { (by 2-DE) }\end{array}$ & $\begin{array}{l}\text { mRNA level } \\
\text { (by qRT-PCR) }\end{array}$ \\
\hline 1 & rpsA gene product [Edwardsiella tarda EIB202]: 30 S ribosomal protein S1 & Down $(0.42 \pm 0.05)$ & Unchanged \\
\hline 2 & hypothetical protein1 [Edwardsiella tarda ElB202]: & Down $(-\infty)$ & Down $(0.38 \pm 0.06)$ \\
\hline 3 & tuf2 gene product [Edwardsiella tarda EIB202]: elongation factor Tu & Down $(0.35 \pm 0.09)$ & Unchanged \\
\hline 4 & Putative carbamoyltransferase YgeW [Edwardsiella tarda ATCC 23685] & Down $(0.21 \pm 0.12)$ & Down $(0.42 \pm 0.09)$ \\
\hline 5 & Mrp(Multiple Resistance and pH adaptation) protein [Edwardsiella tarda FL6-60] & Up $(2.81 \pm 1.11)$ & Up $(4.11 \pm 0.85)$ \\
\hline 6 & tsf gene product [Edwardsiella tarda EIB202]: translation elongation factor Ts & Down $(0.45 \pm 0.07)$ & Unchanged \\
\hline 7 & Dyp-type peroxidase family protein [Edwardsiella tarda EIB202] & Up $(3.62 \pm 0.78)$ & Up $(7.72 \pm 1.08)$ \\
\hline 8 & ybaS gene product [Edwardsiella tarda EIB202]: glutaminase & Down $(-\infty)$ & Down $(0.20 \pm 0.07)$ \\
\hline 9 & Hypothetical protein [Edwardsiella tarda EIB202]: Iysophospholipase & Up $(3.21 \pm 1.28)$ & Up $(5.10 \pm 0.84)$ \\
\hline 10 & fkpA gene product [Edwardsiella tarda ElB202]: FKBP-type peptidyl-prolyl cis-trans isomerase & Up $(4.24 \pm 1.35)$ & Up $(7.54 \pm 1.21)$ \\
\hline 11 & ompR gene product [Edwardsiella tarda EIB202]: osmolarity response regulator; cytoplasmic & Down $(-\infty)$ & Down $(0.18 \pm 0.04)$ \\
\hline 12 & iscU gene product [Edwardsiella tarda ElB202]: FeS cluster assembly scaffold & Up $(2.23 \pm 0.62)$ & Unchanged \\
\hline 13 & Uncharacterized membrane protein YqjD [Edwardsiella tarda FL6-60] & Down $(0.25 \pm 0.04)$ & Down $(0.54 \pm 0.05)$ \\
\hline 14 & Putative iron-containing alcohol dehydrogenase [Edwardsiella tarda FL6-60] & Down $(0.27 \pm 0.06)$ & Unchanged \\
\hline 15 & Cysteine synthase [Edwardsiella tarda C07-087] & Down $(0.46 \pm 0.05)$ & Down $(0.33 \pm 0.08)$ \\
\hline
\end{tabular}

that Hfq plays a critical role in the regulation of iron homeostasis [36-40]. Biofilm growth is a dynamic process with multiple factors involved [41]. Recent studies showed that the major biofilm regulator CsgD was regulated by Hfq-dependent sRNAs in E. coli and Actinobacillus pleuropneumoniae [42,43], and that in E. coli, Pseudomonas fluorescens, Vibrio alginolyticus, and Stenotrophomonas maltophilia, biofilm development was reduced in the absence of Hfq [20,44-46]. Likewise, in our study we found that TXhfq was impaired in the capacity of biofilm production. These results indicate that in E. tarda, Hfq is required for both planktonic and biofilm growth. Since for bacterial pathogens, biofilm production is often associated with infectivity, these observations suggest that $\mathrm{Hfq}$ possibly plays a role under both physiological conditions and during bacterial infection.

Reports have shown that $\mathrm{Hfq}$ is essential to cellular tolerance of various stresses, such as oxidative damage, high salt, and heat shock, in a variety of bacteria including Serratia sp, E. coli, Francisella tularensis, K. pneumoniae, and $V$. alginolyticus [19,47]. However, in other bacteria such as Listeria monocytogenes, Haemophilus influenzae, and Staphylococcus aureus, Hfq has no effect on resistance to oxidative stress $[34,48]$. In the case of E. tarda, we found that in the presence of the strong oxidizer $\mathrm{H}_{2} \mathrm{O}_{2}$, the survival rate of TXhfq was significantly lower than that of TX01, suggesting that Hfq is required for coping with oxidative stress in E. tarda. Given the fact that production of reactive oxygen species, which induces a state of oxidative stress, is a key defense mechanism in fish as well as mammals against bacterial pathogens, these results indicate a potential involvement of $\mathrm{Hfq}$ in the virulence E. tarda.

A large amount of evidences have indicated that $\mathrm{Hfq}$ plays a role in pathogenicity. For example, mutation of $h f q$ affects the ability of Brucella melitensis and Salmonella enterica serovar Typhimurium to invade and proliferate inside host cells $[49,50]$. Similar to these observations, we found that TXhfq exhibited a dramatically increased $\mathrm{LD}_{50}$, and, consistently, the ability of TXhfq to disseminate in flounder tissues and replicate in HK macrophages was significantly impaired. In addition, we found that HK macrophages infected with TXhfq produced much higher levels of ROS and NO than macrophages infected with TX01, suggesting that TXhfq was defective in blocking macrophage activation. In agreement with these results, TXhfq exhibited reduced capacity to survive and replicate inside HK macrophages. These results indicate that Hfq is essential for effective repression of the bactericidal immune response of host cells. Previous studies have shown that E. tarda is an intracellular pathogen that can escape host immune defense and replicate in host phagocytes [51-53]; however, the mechanism behind this phenomenon is unclear. Our results confirm previous observations and suggest a close link between immune evasion and E. tarda virulence. More importantly, our results, together with those of previous reports, point to a possibility that the intracellular replication capacity of $E$. tarda is not due to the action of a single bacterial factor but more likely to the combined effects of multiple factors.

Hfq is known to regulate gene expression and mRNA stability in post-transcription level, resulting in changes 


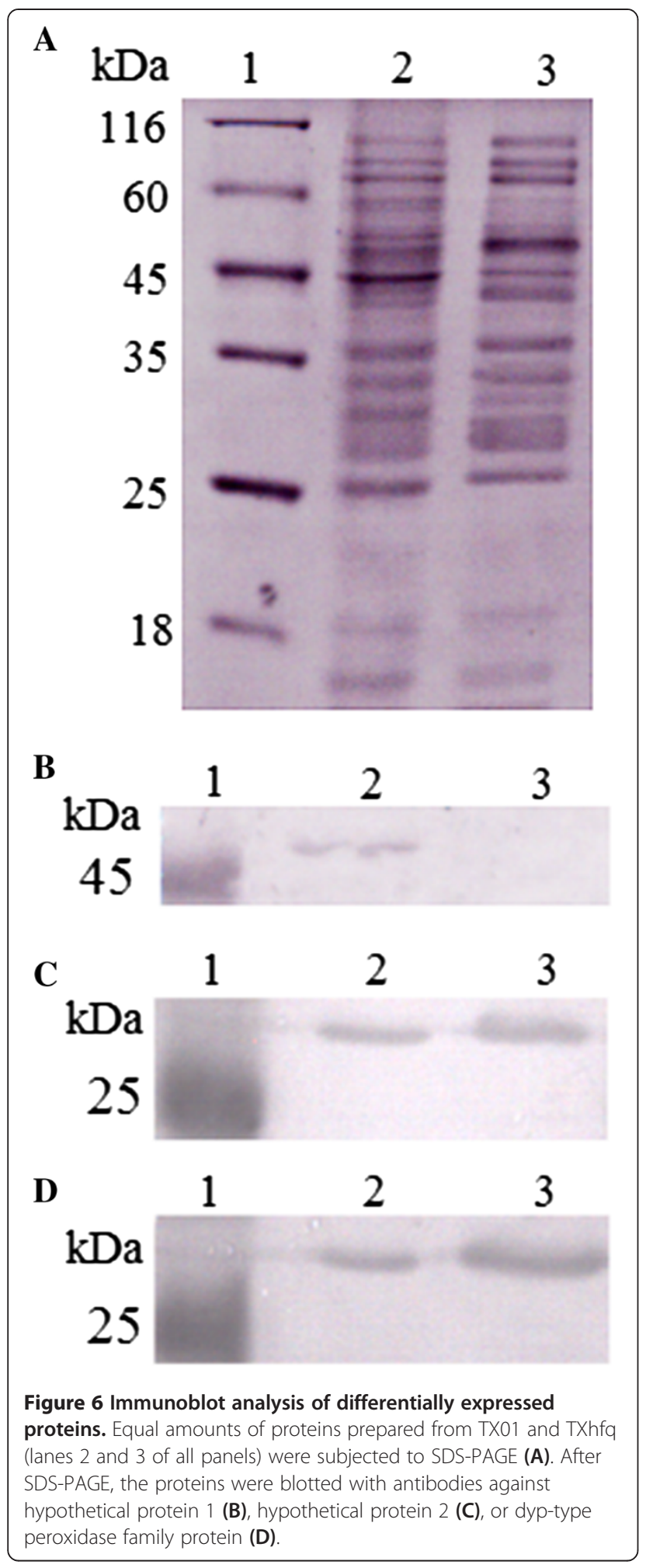

in protein production. Hence, proteomics is an appropriate strategy to detect putative targets of Hfq. Using this approach, Hfq regulons have been identified in Salmonella, Sinorhizobium meliloti, and Neisseria meningitides [39,54-57]. In this study, global proteomic analysis identified 15 proteins differentially expressed between TXhfq and TX01. Of these proteins, YgeW is a carbamoyltransferase that is likely involved in the biosynthesis of antibiotic [58], YbaS is a glutaminase known to contribute to acid resistance $[59,60]$, iron-containing alcohol dehydrogenase and cysteine synthase have been reported to participate in regulation of ethanol utilization and production of antioxidant respectively [61,62], YqjD is an inner membrane protein associated with stationaryphase ribosomes [63], and OmpR is an outer membrane protein that is essential for low $\mathrm{pH}$ adaptation and regulates the virulence-associated type VI secretion system [64]. The downregulated expression of these proteins observed in TXhfq may account in part for the defectiveness of TXhfq in growth and in coping with stress conditions. qRT-PCR analysis of the genes encoding the 15 differentially expressed proteins showed that for ten genes, the mRNA levels were consistent with the 2-DE results, while for five genes, the mRNA levels were comparable between TXhfq and TX01. These results suggest that in most cases Hfq regulates the target genes at the transcription level, while in some cases Hfq regulates the target genes at the posttranscriptional level. It will be interesting for future studies to delineate the detail process of $\mathrm{Hfq}$ regulation of different types of targets. In addition, since none of the differentially expressed proteins has been studied in E. tarda, works may be carried out in the future to inactivate these proteins (e.g. by gene knock-out) and investigate the potential significance of these proteins in E. tarda survival under different conditions.

Since Hfq wild types usually exhibit vitiated virulence, they are ideal targets for the development of attenuated live vaccines. This idea has been exploited by researchers with different pathogenic species such as S. enterica serovar Typhimurium, Brucella melitensis, and V. alginolyticus $[45,65,66]$. In our study, we found that flounder immunized with live TXhfq via bath immersion exhibited high levels of survival rates at one- and two-month post-vaccination after lethal $E$. tarda challenge, suggesting that TXhfq confers effective protection against E. tarda. Given the fact that TXhfq, though highly attenuated in virulence, is still capable of transient infection into flounder via immersion as observed in the tissue dissemination analysis, it is likely that TXhfq mimics natural infection after immersion vaccination and thus induces strong protective immunity in the host. The advantage of TXhfq as a vaccine lies not only in its protectivity but also in its immersion delivery, which for fish is a natural approach. Compared to the commonly used injection method of vaccine delivery, immersion is of low cost and inflicts no stress upon the animals.

In conclusion, we demonstrate in this study that $h f q$ knockout affects multiple aspects of E. tarda, which 
results in dramatic attenuation of infectivity. Hfq is required for the expression of a wide range of proteins belonging to different functional categories, and the regulatory effects of Hfq likely exert at both transcription and post-transcription levels. In addition, the $\Delta h f q$ wild type as an immersion vaccine induces effective immunoprotection, a property that may be exploited for the control of E. tarda in aquaculture.

\section{Additional file}

Additional file 1: Biofilm production of TX01 and TXhfq. TX01 and

TXhfa were grown in polystyrene plates for $24 \mathrm{~h}$ and then assayed for biofilm production. Data are presented as means $\pm E(N=3) .{ }^{* *}, P<0.01$.

\section{Competing interests}

The authors declare that they have no competing interests.

\section{Authors' contributions}

YHH and YXL performed the experiments and analyzed the data. LS designed the experiment. LS and YHH wrote the paper. All authors read and approved the final manuscript.

\section{Acknowledgements}

This work was supported by the grants from the National Natural Science Foundation of China (31330081, 31302223, and 31025030) and the Taishan Scholar Program of Shandong Province.

\section{Author details}

'Key Laboratory of Experimental Marine Biology, Institute of Oceanology, Chinese Academy of Sciences, Qingdao 266071, China. ${ }^{2}$ Taishan Vocational College of Nursing, 8 Ying Sheng East Road,Tai'an 271000, China.

Received: 15 December 2013 Accepted: 13 February 2014 Published: 25 February 2014

\section{References}

1. Mohanty BR, Sahoo PK: Edwardsiellosis in fish: a brief review. J Biosci 2007, 32:1331-1344.

2. Park SB, Aoki T, Jung TS: Pathogenesis of and strategies for preventing Edwardsiella tarda infection in fish. Vet Res 2012, 43:67.

3. Nelson JJ, Nelson CA, Carter JE: Extraintestinal manifestations of Edwardsiella tarda infection: a 10-year retrospective review. J La State Med Soc 2009, 161:103-106.

4. Leung KY, Siame BA, Tenkink BJ, Noort RJ, Mok YK: Edwardsiella tardavirulence mechanisms of an emerging gastroenteritis pathogen. Microbes Infect 2012, 14:26-34.

5. de Fernandez MT F, Eoyang L, August JT, de Fernandez MT F, Eoyang L, August JT: Factor fraction required for the synthesis of bacteriophage QBeta-RNA. Nature 1968, 219:588-590.

6. De Lay N, Schu DJ, Gottesman S: Bacterial small RNA-based negative regulation: Hfq and its accomplices. J Biol Chem 2013, 288:7996-8003.

7. Vogel J, Luisi BF: Hfq and its constellation of RNA. Nat Rev Microbiol 2011, 9:578-589.

8. Bibova I, Skopova K, Masin J, Cerny O, Hot D, Sebo P, Vecerek B: The RNA chaperone $\mathrm{Hfq}$ is required for virulence of Bordetella pertussis. Infect Immun 2013, 81:4081-4090.

9. Bojer MS, Jakobsen H, Struve C, Krogfelt KA, Løbner-Olesen A: Lack of the RNA chaperone $\mathrm{Hfq}$ attenuates pathogenicity of several Escherichia coli pathotypes towards Caenorhabditis elegans. Microbes Infect 2012, 14:1034-1309.

10. Caswell CC, Gaines JM, Roop RM 2nd: The RNA chaperone Hfa independently coordinates expression of the VirB type IV secretion system and the LuxR-type regulator BabR in Brucella abortus 2308. J Bacteriol 2012, 194:3-14.
11. Chiang MK, Lu MC, Liu LC, Lin CT, Lai YC: Impact of Hfq on global gene expression and virulence in Klebsiella pneumoniae. PLoS One 2011, 6:e22248.

12. Ding $Y$, Davis BM, Waldor MK: Hfq is essencial for Vibrio cholera virulence and dowregulates sigma expression. Mol Microbiol 2004, 53:345-354.

13. Meng X, Meng X, Zhu C, Wang H, Wang J, Nie J, Hardwidge PR, Zhu G: The RNA chaperone $\mathrm{Hfq}$ regulates expression of fimbrial-related genes and virulence of Salmonella enterica serovar Enteritidis. FEMS Microbiol Lett 2013, 346:90-96

14. Nakao H, Watanabe $\mathrm{H}$, Nakayama S, Takeda T: yst gene expression in Yersinia enterocolitica is positively regulated by a chromosomal region that is highly homologous to Escherichia coli host factor 1 gene ( $h f q)$. Mol Microbiol 2005, 18:859-865.

15. Sittka A, Pfeiffer V, Tedin $K$, Vogel J: The RNA chaperone Hfq is essential for the virulence of Salmonella typhimurium. Mol Microbiol 2007, 63:193-217.

16. Sonnleitner E, Hagens S, Rosenau F, Wilhelm S, Habel A, Jäger KE, Bläsi U: Reduced virulence of a $h f q$ wild type of Pseudomonas aeruginosa 01 . Microb Pathol 2003, 35:217-228.

17. Wilms I, Möller P, Stock AM, Gurski R, Lai EM, Narberhaus F: Hfq influences multiple transport systems and virulence in the plant pathogen Agrobacterium tumefaciens. J Bacteriol 2012, 194:5209-5217.

18. Zeng Q, McNally RR, Sundin GW: Global small RNA chaperone Hfq and regulatory small RNAs are important virulence regulators in Erwinia amylovora. J Bacteriol 2013, 195:1706-1717.

19. Chao Y, Vogel J: The role of Hfq in bacterial pathogens. Curr Opin Microbiol 2010, 13:24-33.

20. Roscetto E, Angrisano T, Costa V, Casalino M, Förstner KU, Sharma CM, Di Nocera PP, De Gregorio E: Functional characterization of the RNA chaperone $\mathrm{Hfq}$ in the opportunistic human pathogen Stenotrophomonas maltophilia. J Bacteriol 2012, 194:5864-5874.

21. Sun K, Wang HL, Zhang M, Xiao ZZ, Sun L: Genetic mechanisms multiantimicrobial resistance in a pathogenic Edwardsiella tarda strain. Aquaculture 2009, 289:134-139.

22. Hu YH, Liu CS, Hou JH, Sun L: Identification, characterization, and molecular application of a virulence-associated autotransporter from a pathogenic Pseudomonas fluorescens strain. Appl Environ Microbiol 2009, 75:4333-4340.

23. Wang HR, Hu YH, Zhang WW, Sun L: Construction of an attenuated Pseudomonas fluorescens strain and evaluation of its potential as a cross-protective vaccine. Vaccine 2009, 27:4047-4055.

24. Milton DL, O'Toole R, Horstedt P, Wolf-Watz H: Flagellin A is essential for the virulence of Vibrio anguillarum. J Bacteriol 1996, 178:1310-1319.

25. Zhang WW, Sun K, Cheng S, Sun L: Characterization of DegQVh, a serine protease and a protective immunogen from a pathogenic Vibrio harveyi strain. Appl Environ Microbiol 2008, 74:6254-6262.

26. $\mathrm{Hu} Y \mathrm{YH}$, Wang $\mathrm{HL}$, Zhang $M$, Sun $L$ : Molecular analysis of the copperresponsive CopRSCD of a pathogenic Pseudomonas fluorescens strain. J Microbiol 2009, 47:277-286.

27. Zheng WJ, Hu YH, Sun L: The two Dps of Edwardsiella tarda are involved in resistance against oxidative stress and host infection. Fish Shellfish Immunol 2011, 31:985-992.

28. Liu CS, Sun Y, Hu YH, Sun L: Identification and analysis of the immune effects of CpG motifs that protect Japanese flounder (Paralichthys olivaceus) against bacterial infection. Fish Shellfish Immunol 2010, 29:279-285.

29. Zhang J, Hu YH, Xiao ZZ, Sun L: Megalocytivirus-induced proteins of turbot (Scophthalmus maximus): identification and antiviral potential. J Proteomics 2013, 91:430-443.

30. Zheng WJ, Sun L: Evaluation of housekeeping genes as references for quantitative real time RT-PCR analysis of gene expression in Japanese flounder (Paralichthys olivaceus). Fish Shellfish Immunol 2011, 30:638-645.

31. Liu CS, Sun Y, Zhang M, Sun L: Identification and analysis of a Sciaenops ocellatus ISG15 homologue that is involved in host immune defense against bacterial infection. Fish Shellfish Immunol 2010, 29:167-174.

32. Sun Y, Zheng WJ, Hu YH, Sun BG, Sun L: Edwardsiella tarda Eta1, an in vivo-induced antigen that is involved in host infection. Infect Immun 2012, 80:2948-2955.

33. Sun Y, Liu CS, Sun L: Identification of an Edwardsiella tarda surface antigen and analysis of its immunoprotective potential as a purified recombinant subunit vaccine and a surface-anchored subunit vaccine expressed by a fish commensal strain. Vaccine 2010, 28:6603-6608. 
34. Hempel RJ, Morton DJ, Seale TW, Whitby PW, Stull TL: The role of the RNA chaperone $\mathrm{Hfq}$ in Haemophilus influenzae pathogenesis. BMC Microbiol 2013, 13:134.

35. Wilf NM, Williamson NR, Ramsay JP, Poulter S, Bandyra KJ, Salmond GP: The RNA chaperone, Hfq, controls two luxR-type regulators and plays a key role in pathogenesis and production of antibiotics in Serratia sp. ATCC 39006. Environ Microbiol 2011, 13:2649-2666.

36. Bearson BL, Bearson SM, Uthe JJ, Dowd SE, Houghton JO, Lee I, Toscano MJ, Lay DC Jr: Iron regulated genes of Salmonella enterica serovar Typhimurium in response to norepinephrine and the requirement of fepDGC for norepinephrine-enhanced growth. Microbes Infect 2008, 10:807-816.

37. Mellin JR, McClure R, Lopez D, Green O, Reinhard B, Genco C: Role of Hfq in iron-dependent and -independent gene regulation in Neisseria meningitidis. Microbiology 2010, 56:2316-2326.

38. Metruccio MM, Fantappiè L, Serruto D, Muzzi A, Roncarati D, Donati C, Scarlato V, Delany I: The Hfq-dependent small noncoding RNA NrrF directly mediates Fur-dependent positive regulation of succinate dehydrogenase in Neisseria meningitidis. J Bacteriol 2009, 191:1330-1342.

39. Sobrero P, Schlüter JP, Lanner U, Schlosser A, Becker A, Valverde C: Quantitative proteomic analysis of the Hfq-regulon in Sinorhizobium meliloti 2011. PLoS One 2012, 7:e48494.

40. Vecerek B, Moll I, Afonyushkin T, Kaberdin V, Blasi U: Interaction of the RNA chaperone $\mathrm{Hfq}$ with mRNAs: direct and indirect roles of $\mathrm{Hfq}$ in iron metabolism of Escherichia coli. Mol Microbiol 2003, 50:897-909.

41. Salazar JK, Wu Z, Yang W, Freitag NE, Tortorello ML, Wang H, Zhang W: Roles of a novel Crp/Fnr family transcription factor Lmo0753 in soil survival, biofilm production and surface attachment to fresh produce of Listeria monocytogenes. PLoS One 2013, 8:e75736.

42. Mika F, Busse S, Possling A, Berkholz J, Tschowri N, Sommerfeldt N, Pruteanu $M$, Hengge R: Targeting of csgD by the small regulatory RNA RprA links stationary phase, biofilm formation and cell envelope stress in Escherichia coli. Mol Microbiol 2012, 84:51-65.

43. Subashchandrabose S, Leveque RM, Kirkwood RN, Kiupel M, Mulks MH: The RNA chaperone Hfq promotes fitness of Actinobacillus pleuropneumoniae during porcine pleuropneumonia. Infect Immun 2013, 81:2952-2961.

44. Kulesus RR, Diaz-Perez K, Slechta ES, Eto DS, Mulvey MA: Impact of the RNA chaperone $\mathrm{Hfq}$ on the fitness and virulence potential of uropathogenic Escherichia coli. Infect Immun 2008, 76:3019-3026.

45. Liu H, Wang Q, Liu Q, Cao X, Shi C, Zhang Y: Roles of Hfq in the stress adaptation and virulence in fish pathogen Vibrio alginolyticus and its potential application as a target for live attenuated vaccine. Appl Microbiol Biotechnol 2011, 91:353-364

46. Wu XG, Duan HM, Tian T, Yao N, Zhou HY, Zhang LQ: Effect of the hfq gene on 2,4-diacetylphloroglucinol production and the Pcol/PcoR quorum-sensing system in Pseudomonas fluorescens 2P24. FEMS Microbiol Lett 2010, 309:16-24.

47. Christiansen JK, Larsen $M H$, Ingmer $H$, Sogaard-Andersen L, Kallipolitis BH: The RNA-binding protein Hfq of Listeria monocytogenes: role in stress tolerance and virulence. J Bacteriol 2004, 186:3355-3362.

48. Bohn C, Rigoulay C, Bouloc P: No detectable effect of RNA-binding protein Hfq absence in Staphylococcus aureus. BMC Microbiol 2007, 7:10.

49. Cui M, Wang T, Xu J, Ke Y, Du X, Yuan X, Wang Z, Gong C, Zhuang Y, Lei S, Su X, Wang X, Huang L, Zhong Z, Peng G, Yuan J, Chen Z, Wang Y: Impact of $\mathrm{Hfq}$ on global gene expression and intracellular survival in Brucella melitensis. PLoS One 2013, 8:e71933.

50. Viegas SC, Mil-Homens D, Fialho AM, Arraiano CM: The Virulence of Salmonella enterica Serovar Typhimurium in the insect model galleria mellonella is impaired by mutations in RNase E and RNase III. Appl Environ Microbiol 2013, 79:6124-6133.

51. Cheng $S$, Zhang M, Sun L: The iron-cofactored superoxide dismutase of Edwardsiella tarda inhibits macrophage-mediated innate immune response. Fish Shellfish Immunol 2010, 29:972-978.

52. Ishibe K, Osatomi K, Hara K, Kanai K, Yamaguchi K, Oda T: Comparison of the responses of peritoneal macrophages from Japanese flounder (Paralichthys olivaceus) against high virulent and low virulent strains of Edwardsiella tarda. Fish Shellfish Immunol 2008, 24:243-251.

53. Rao PSS, Lim TM, Leung KY: Opsonized virulent Edwardsiella tarda strains are able to adhere to and survive and replicate within fish phagocytes but fail to stimulate reactive oxygen intermediates. Infect Immun 2001, 69:5689-5697.
54. Ansong $\mathrm{C}$, Yoon $\mathrm{H}$, Porwollik S, Mottaz-Brewer $\mathrm{H}$, Petritis $\mathrm{BO}$, Jaitly $\mathrm{N}$, Adkins JN, MCClelland M, Heffron F, Smith RD: Global systems-level analysis of $\mathrm{Hfq}$ and SmpB deletion wild types in Salmonella: implications for virulence and global protein translation. PLoS One 2009, 4:e4809.

55. Barra-Bily L, Fontenelle C, Jan G, Flechard M, Trautwetter A, Pandey SP, Walker GC, Blanco C: Proteomic alterations explain phenotypic changes in Sinorhizobium meliloti lacking the RNA chaperone Hfq. J Bacterio/ 2010, 192:1719-1729.

56. Fantappie L, Metruccio MM, Seib KL, Oriente F, Cartocci E, Ferlicca F, Giuliani MM, Scarlato V, Delany I: The RNA chaperone Hfq is involved in the stress response and virulence in Neisseria meningitidis and is a pleiotropic regulator of protein expression. Infect Immun 2009, 77:1842-1853.

57. Pannekoek Y, Huis in't Veld R, Hopman CT, Langerak AA, Speijer D, van der Ende A: Molecular characterization and identification of proteins regulated by Hfq in Neisseria meningitidis. FEMS Microbiol Lett 2009, 294:216-224.

58. Hong YS, Lee D, Kim W, Jeong JK, Kim CG, Sohng JK, Lee JH, Paik SG, Lee JJ: Inactivation of the carbamoyltransferase gene refines post-polyketide synthase modification steps in the biosynthesis of the antitumor agent geldanamycin. J Am Chem Soc 2004, 126:11142-11143.

59. Brown G, Singer A, Proudfoot M, Skarina T, Kim Y, Chang C, Dementieva I, Kuznetsova E, Gonzalez CF, Joachimiak A, Savchenko A, Yakunin AF: Functional and structural characterization of four glutaminases from Escherichia coli and Bacillus subtilis. Biochemistry 2008, 47:5724-5735.

60. Lu P, Ma D, Chen Y, Guo Y, Chen GQ, Deng H, Shi Y: L-glutamine provides acid resistance for Escherichia coli through enzymatic release of ammonia. Cell Res 2013, 23:635-644.

61. Hempel N, Görisch H, Mern DS: Gene ercA encoding a putative ironcontaining alcohol dehydrogenase is involved in regulation of ethanol utilization in Pseudomonas aeruginosa. J Bacteriol 2013, 195:3925-3932.

62. O'Leary SE, Jurgenson CT, Ealick SE, Begley TP: O-phospho-L-serine and the thiocarboxylated sulfur carrier protein $\mathrm{CysO}-\mathrm{COSH}$ are substrates for CysM, a cysteine synthase from Mycobacterium tuberculosis. Biochemistry 2008, 47:11606-11615.

63. Yoshida H, Maki Y, Furuike S, Sakai A, Ueta M, Wada A: YqjD is an inner membrane protein associated with stationary-phase ribosomes in Escherichia coli. J Bacteriol 2012, 194:4178-4183.

64. Zhang $W$, Wang $Y$, Song $Y$, Wang $T$, Xu S, Peng Z, Lin X, Zhang L, Shen X: A type $\mathrm{VI}$ secretion system regulated by OmpR in Yersinia pseudotuberculosis functions to maintain intracellular $\mathrm{pH}$ homeostasis. Environ Microbiol 2013, 15:557-569.

65. Allam US, Krishna MG, Lahiri A, Joy O, Chakravortty D: Salmonella enterica serovar Typhimurium lacking hfq gene confers protective immunity against murine typhoid. PLoS One 2011, 6:e16667.

66. Zhang J, Guo F, Chen C, Li Z, Zhang H, Wang Y, Zhang K, Du G, Li Y, Wang J, Jian T, Wang Z: Brucella melitensis $16 \mathrm{M} \Delta \mathrm{hfq}$ attenuation confers protection against wild-type challenge in BALB/c mice. Microbiol Immunol 2013, 57:502-510.

doi:10.1186/1297-9716-45-23

Cite this article as: Hu et al:: Edwardsiella tarda Hfq: impact on host infection and global protein expression. Veterinary Research 2014 45:23.

\section{Submit your next manuscript to BioMed Central and take full advantage of:}

- Convenient online submission

- Thorough peer review

- No space constraints or color figure charges

- Immediate publication on acceptance

- Inclusion in PubMed, CAS, Scopus and Google Scholar

- Research which is freely available for redistribution 